Article

\title{
Luteolin-3'-O-Phosphate Inhibits Lipopolysaccharide-Induced Inflammatory Responses by Regulating NF-KB/MAPK Cascade Signaling in RAW 264.7 Cells
}

\author{
Jung-Hwan Kim ${ }^{1}\left(\right.$, Tae-Jin Park ${ }^{1}{ }^{\circledR}$, Jin-Soo Park ${ }^{2}{ }^{\oplus}$, Min-Seon Kim ${ }^{2}$, Won-Jae Chi ${ }^{3}$ and Seung-Young Kim ${ }^{1, *}$ \\ 1 Department of Pharmaceutical Engineering \& Biotechnology, Sunmoon University, Asan 31460, Korea; \\ k5991313@naver.com (J.-H.K.); bark.taejin@gmail.com (T.-J.P.) \\ 2 Natural Product Informatics Research Center, Korea Institute of Science and Technology (KIST), \\ Gangneung 25451, Korea; jinsoopark@kist.re.kr (J.-S.P.); nari7040@gmail.com (M.-S.K.) \\ 3 Genetic Resources Assessment Division, National Institute of Biological Resources, Incheon 22689, Korea; \\ wjchi76@korea.kr \\ * Correspondence: sykim01@sunmoon.ac.kr; Tel.: +82-41-530-2390
}

Citation: Kim, J.-H.; Park, T.-J.; Park, J.-S.; Kim, M.-S.; Chi, W.-J.; Kim, S.-Y. Luteolin-3'-O-Phosphate Inhibits Lipopolysaccharide-Induced Inflammatory Responses by Regulating NF-кB/MAPK Cascade Signaling in RAW 264.7 Cells. Molecules 2021, 26, 7393. https: / / doi.org/10.3390/ molecules26237393

Academic Editors: Jongsung Lee and Chang-Gu Hyun

Received: 9 November 2021

Accepted: 2 December 2021

Published: 6 December 2021

Publisher's Note: MDPI stays neutral with regard to jurisdictional claims in published maps and institutional affiliations.

Copyright: (c) 2021 by the authors. Licensee MDPI, Basel, Switzerland. This article is an open access article distributed under the terms and conditions of the Creative Commons Attribution (CC BY) license (https:// creativecommons.org/licenses/by/ $4.0 /)$.
Abstract: Luteolin (LT), present in most plants, has potent anti-inflammatory properties both in vitro and in vivo. Furthermore, some of its derivatives, such as luteolin-7-O-glucoside, also exhibit antiinflammatory activity. However, the molecular mechanisms underlying luteolin-3'-O-phosphate (LTP)-mediated immune regulation are not fully understood. In this paper, we compared the antiinflammatory properties of LT and LTP and analyzed their molecular mechanisms of action; we obtained LTP via the biorenovation of LT. We investigated the anti-inflammatory activities of LT and LTP in macrophage RAW 264.7 cells. We confirmed from previously reported literature that LT inhibits the production of nitric oxide and prostaglandin $\mathrm{E}_{2}$, as well as the expression of inducible NO synthetase and cyclooxygenase-2. In addition, expressions of inflammatory genes and mediators, such as tumor necrosis factor- $\alpha$, interleukin- 6 , and interleukin- $1 \beta$, were suppressed. LTP showed anti-inflammatory activity similar to LT, but better anti-inflammatory activity in all the experiments, while also inhibiting mitogen-activated protein kinase and nuclear factor-kappa B more effectively than LT. At a concentration of $10 \mu \mathrm{M}$, LTP showed differences of 2.1 to $44.5 \%$ in the activity compared to LT; it also showed higher anti-inflammatory activity. Our findings suggest that LTP has stronger anti-inflammatory activity than LT.

Keywords: luteolin-3'-O-phosphate; anti-inflammatory; MAPK; NF-kB; biorenovation

\section{Introduction}

Inflammation is a unique limiting process for the identification and destruction of invading pathogens; it is achieved through biological reactions that occur in the human body, and it restores normal tissue structure and function [1-4]. Normal inflammation is caused by an immune response to adverse stimuli or the upregulation of anti-inflammatory cytokines [5]. However, chronic inflammation is associated with an increased risk of tissue damage and the production of inflammatory cytokines [6]. The stimulation of macrophages with lipopolysaccharide (LPS) induces the production of nitric oxide (NO) and inflammatory cytokines, such as tumor necrosis factor (TNF- $\alpha$ ), interleukin-6 (IL-6), and interleukin-1 $\beta$ (IL-1 $\beta$ ) [7]. NO regulates the pathological and physiological conditions for reactive radicals produced by inducible nitric oxide synthase (iNOS) [8]. However, NO overexpression induces adverse reactions, such as acute or chronic inflammatory diseases and tissue damage [9]. Prostaglandin (PG) is produced in most cells in the body and synthesized in arachidonic acid through the action of cyclooxygenase (COX) enzymes as a stimulus to cells. Among them, $\mathrm{PGE}_{2}$ is the most prostanoid in the body and exhibits inflammatory or, in some cases, anti-inflammatory effects [10]. IL-6 and TNF- $\alpha$ can both induce the progression of inflammation via iNOS and COX-2 [11]. In addition, nuclear 
factor-kappa B (NF- $\mathrm{kB}$ ) regulates the expression of pro-inflammatory cytokines when activated by inflammatory stimulation by LPS, a stimulant [12]. Mitogen activated protein kinase (MAPK) is known to include extracellular signal-regulated kinase (ERK), c-jun $\mathrm{NH}_{2}$-terminal kinase (JNK), and p38. MAPKs are involved in inflammatory and immune responses that are activated by stimuli such as LPS. Previous studies have been reported that MAPK plays an important role in the activation of NF- $\mathrm{KB}$ [13-15]. MAPK and NF- $\mathrm{kB}$ are important targets of anti-inflammatory reaction $[16,17]$. Therefore, discovering novel materials (or a novel material) to inhibit the activity of MAPK and NF- $\mathrm{KB}$ was undertaken in this study.

Active research and development are currently being carried out to increase the bioactivity of existing natural products and organic compounds using biorenovation technology $[18,19]$. Among these studies, attempts are being made to improve the biological activities of organic compounds using biorenovation, in which organic compounds are structurally transformed by inducing the enzyme-catalyzed reactions by microorganisms $[20,21]$. Luteolin (LT) is a natural flavonoid found in many plants; it is known to have powerful antioxidant and anti-inflammatory effects [22-24]. Plants with high LT contents have long been used in traditional medicine practices in Brazil, China, and Iran to treat inflammation-related diseases [25]. Hence, natural products are important for the development of new drugs; clinical trials are currently underway for more than 100 drugs derived from natural products [26]. Among flavonoids, LT, in particular, has been actively studied for its anti-inflammatory activity. It is also extracted from various plants for traditional purposes.

Biorenovation methods have been used to study natural products that exhibit better anti-inflammatory activity than conventional substances, such as increasing cell viability or inhibiting NO production $[27,28]$. Among these products, it was hypothesized that LT, which is found in many natural products, could be converted using biorenovation to increase the inhibitory effect compared to its existing anti-inflammatory activity. It was confirmed that the biorenovation of LT produces luteolin-3'-O-phosphate (LTP).

The pharmacological mechanisms of LT and luteolin-7-O-glucoside have been revealed previously [29]. However, the biological activity and pharmacological mechanisms of LTP and LT have not yet been compared. Hence, we compared the differences in the anti-inflammatory activities of LT and LTP using RAW 264.7 cells and investigated the underlying molecular mechanisms of LTP activity.

\section{Results}

\subsection{Analysis and Identification of LT Biorenovation Conversion Products}

The LT biorenovation product separated through the ethyl acetate (EA) fraction was divided into an EA layer and a water layer, and HPLC analysis was performed. As a result, the peaks of the standard LT compound and LTP were confirmed in the water layer (Figure 1a). In the EA layer, the standard LT compound and three significant peaks were detected, but they did not show effective NO inhibitory activity (data not shown). We purified only LTP from the water layer, and the analysis of the LTP using electrospray ionization mass spectrometry (ESIMS) revealed a peak at $\mathrm{m} / \mathrm{z} 286$ (equivalent to LT) (Figure $1 b$ ). These results suggested that LTP is the molecular formula $\mathrm{C}_{15} \mathrm{H}_{11} \mathrm{O}_{9} \mathrm{P}$ as determined using high-resolution ESI/MS (HRESI/MS) and that this compound is in the form of phosphoric acid bound to LT. To our knowledge, this structural LTP has not been previously reported (Figure 1c). 


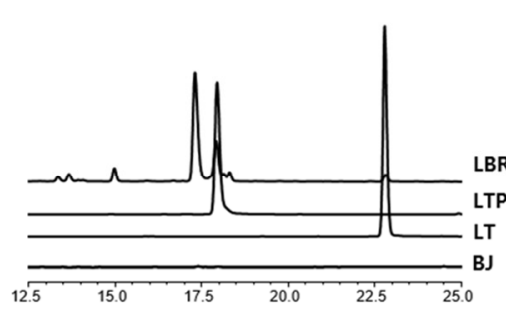

(a)

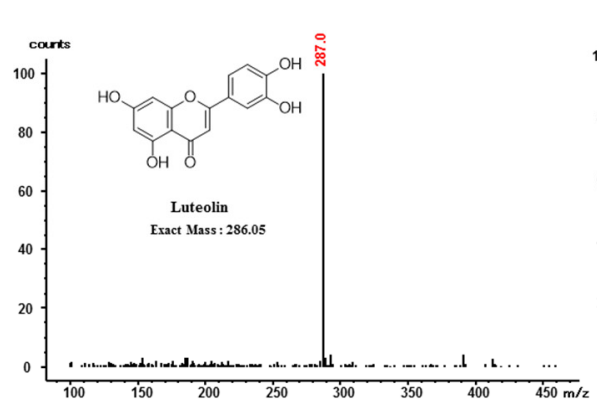

(b)

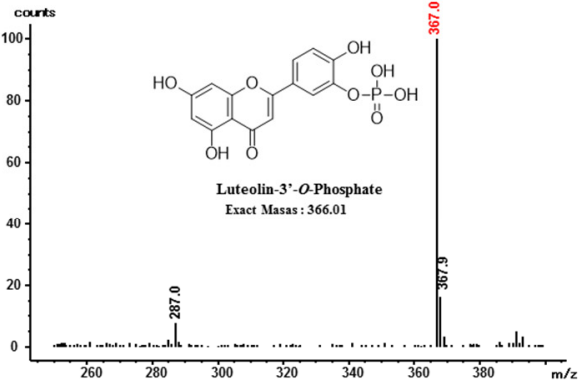

(c)

Figure 1. (a) HPLC analysis of biorenovation negative control (BJ), luteolin biorenovation supernatant (LBR), luteolin (LT), and luteolin-3'-O-phosphate (LTP). (b,c) Mass spectrometry of LT and LTP.

\subsection{Determination of Position of Phosphoryation with NMR Results}

The phosphorylated product was elucidated by NMR spectroscopy data. The ${ }^{1} \mathrm{H}-$ and 2D NMR experiments were done as previously reported [30]. The ${ }^{13} \mathrm{C}$ data were obtained from the ${ }^{1} \mathrm{H}, \mathrm{HSQC}$, and $\mathrm{HMBC}$ data. In the comparison to the ${ }^{1} \mathrm{H}$ NMR spectrum of luteolin as the starting material, the spectrum of the product is characterized by a downfield shift of $\mathrm{H}-2^{\prime}, \mathrm{H}-5^{\prime}$, and $\mathrm{H}-6^{\prime}$ corresponding to the C-ring of flavonoid. In addition, the chemical shift of $\mathrm{C}-3^{\prime}$ in the product was significantly upfield-shifted to $141.47 \mathrm{ppm}$ compared to that of luteolin (145.80 ppm), indicating that the phosphorylation occurred at $3^{\prime}-\mathrm{OH}$ of luteolin. Furthermore, more deshielded adjacent carbons including $\mathrm{C}-2^{\prime}$ and $\mathrm{C}-4^{\prime}$ convinced this phosphorylation.

Luteolin-3'-O-phosphate (LTP): ${ }^{1} \mathrm{H}-\mathrm{NMR}(500 \mathrm{MHz}, \mathrm{DMSO}) \delta 7.71\left(1 \mathrm{H}, \mathrm{s}, \mathrm{H}-2^{\prime}\right), 7.69$ $\left(1 \mathrm{H}, \mathrm{d}, \mathrm{H}-6^{\prime}\right), 6.97\left(1 \mathrm{H}, \mathrm{d}, \mathrm{H}-5^{\prime}\right), 6.73(1 \mathrm{H}, \mathrm{s}, \mathrm{H}-3), 6.47(1 \mathrm{H}, \mathrm{d}, \mathrm{H}-8), 6.2(1 \mathrm{H}, \mathrm{d}, \mathrm{H}-6) .{ }^{13} \mathrm{C}-$ NMR (125 MHz, DMSO) $\delta 182.29$ (C-4), 164.89 (C-7), 163.81 (C-2), 162.1 (C-5), 157.8 (C-9), $153.93\left(\mathrm{C}-4^{\prime}\right), 141.47\left(\mathrm{C}-3^{\prime}\right), 123.83\left(\mathrm{C}-6^{\prime}\right), 121.7\left(\mathrm{C}-1^{\prime}\right), 120.28\left(\mathrm{C}-2^{\prime}\right), 118.67\left(\mathrm{C}-5^{\prime}\right), 104.3$ (C-10), 103.68 (C-3), 99.49 (C-6), 94.5 (C-8) (Supplementary Materials).

\subsection{Cytotoxic Effects of Compounds on RAW 264.7 Cells}

The MTT assays showed that either LT or LTP products exhibited greater than $89 \%$ cell viability, and none were cytotoxic at concentrations of 1, 5, or $10 \mu \mathrm{M}$ (Figure 2).

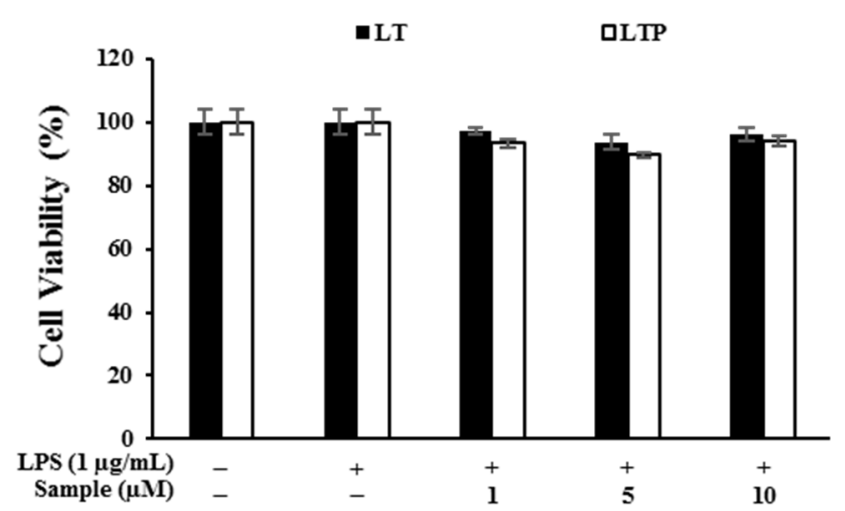

Figure 2. Viability of cells stimulated with LPS $(1 \mu \mathrm{g} / \mathrm{mL})$ for $24 \mathrm{~h}$ in the presence of LT or LTP. Data are expressed as mean \pm standard deviation (SD) from three independent experiments (compared to the LPS-non-treated group).

\subsection{Production of $\mathrm{NO}$ and $P G E_{2}$}

$\mathrm{NO}$ and $\mathrm{PGE}_{2}$ are sub-mechanisms of iNOS and COX-2 and are known to be end products of inflammation. As shown in Figure 3a, both LT and LTP treatments reduced NO production. However, LTP inhibited the NO production more than LT. Regarding the measurement of the $\mathrm{PGE}_{2}$ levels, LT showed inhibition rates of $35.8,49.8$, and $68.1 \%$, 
whereas LTP showed inhibition rates of $56.4,60.8$, and $70.2 \%$ at 1,5 , and $10 \mu \mathrm{M}$, respectively (Figure $3 b$ ). These results indicated that LTP showed a higher $\mathrm{PGE}_{2}$ inhibition rate than LT at low concentrations.

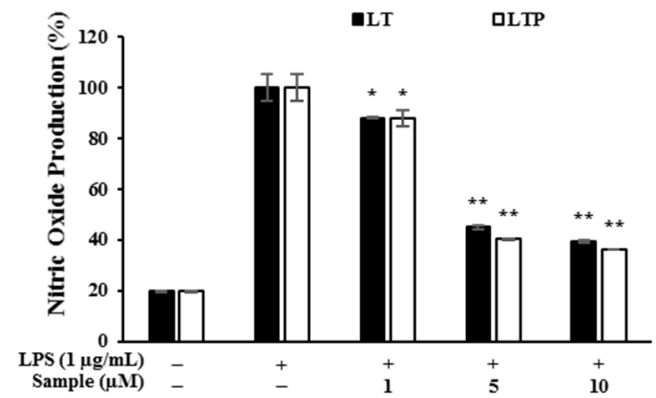

(a)

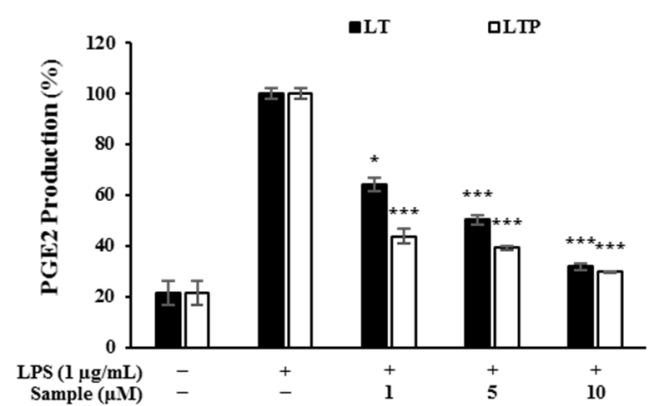

(b)

Figure 3. Effects of LT and LTP (at 1, 5, and $10 \mu \mathrm{M}$ ) on (a) nitric oxide (NO) and (b) prostaglandin E2 (PGE 2 ) production in lipopolysaccharide (LPS)-stimulated RAW264.7 cells. Data are expressed as mean \pm SD from three independent experiments ( $p<0.05,{ }^{* *} p<0.01$, and ${ }^{* * *} p<0.001$, compared to the LPS-treated group).

\subsection{Comparison of iNOS and COX-2 Expression Inhibition}

Both LT and LTP decreased the iNOS expression and COX-2 expression in a concentrationdependent manner, but LTP showed a higher reduction rate than LT at the same experimental concentration (Figure 4a,b). Comparing the inhibition rates of LT and LTP revealed that LTP inhibited iNOS and COX-2 expression more than LT in a dose-dependent manner. These results show that the reductions in the iNOS and COX-2 expression led to the observed $\mathrm{NO}$ and $\mathrm{PGE}_{2}$ production reductions.

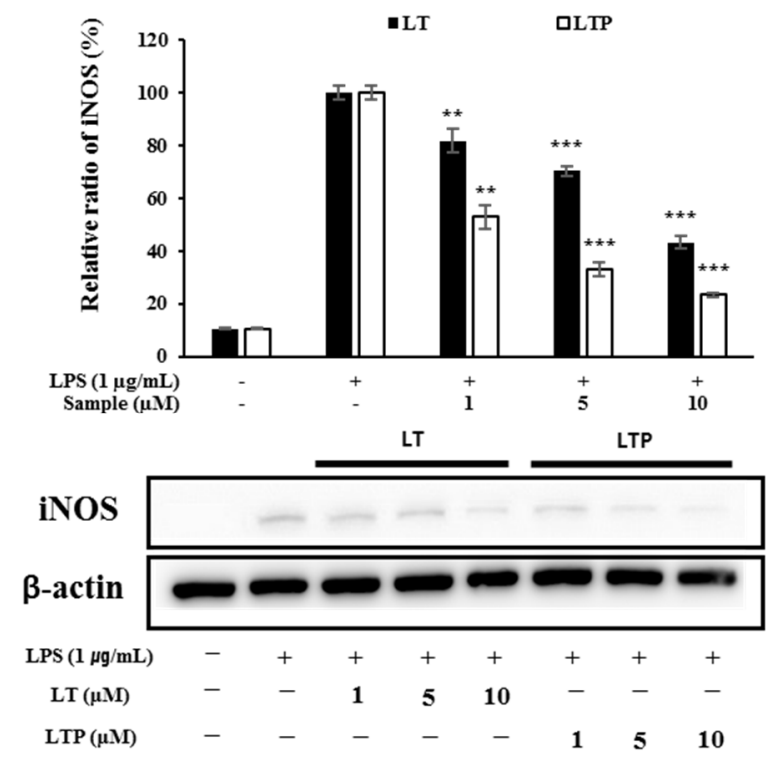

(a)

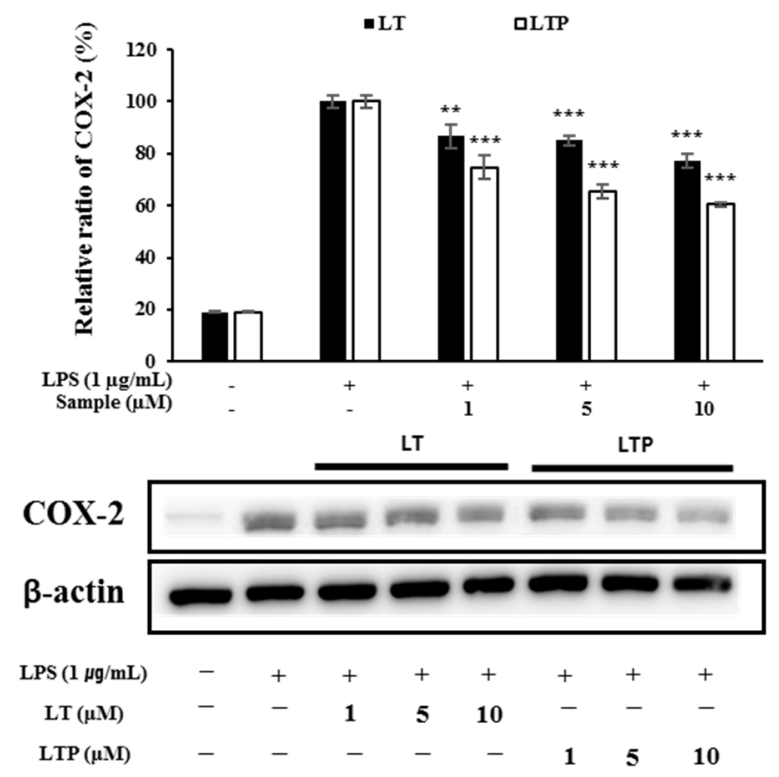

(b)

Figure 4. (a) Inducible NO synthase (iNOS) and (b) cyclooxygenase-2 (COX-2) expression upon LT and LTP treatment in LPS-stimulated RAW264.7 cells. Data are expressed as mean \pm SD from three independent experiments $\left(^{* *} p<0.01\right.$, and *** $p<0.001$, compared to the LPS-treated group).

\subsection{Effects of LT and LTP on LPS-Induced IL-1 $\beta$, IL-6, and TNF- $\alpha$ Expression}

At concentrations of 1,5 , and $10 \mu \mathrm{M}$, LT and LTP decreased the expressions of TNF- $\alpha$, IL-1 $\beta$, and IL-6 in a concentration-dependent manner, as shown in Figure 5. In particular, 
$10 \mu \mathrm{M}$ of LT and LTP inhibited the IL-1 $\beta$ expression by 52.7 and $55.2 \%$ (Figure $5 \mathrm{~b}$ ) and IL-6 expression by 46.3 and 51.4\%, respectively (Figure 5c). Collectively, these results indicate that LTP exhibited an anti-inflammatory effect by suppressing the expressions of the proinflammatory cytokines TNF- $\alpha$, IL-1 $\beta$, and IL-6 more compared to LT.

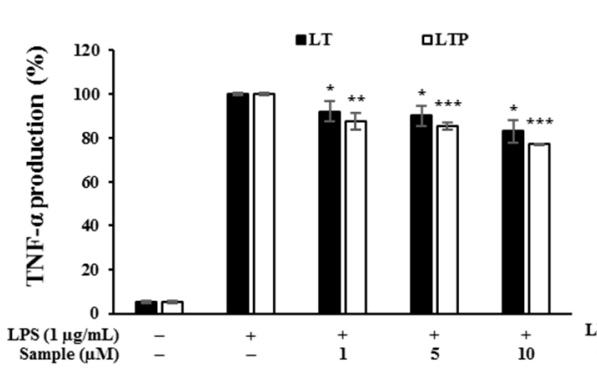

(a)

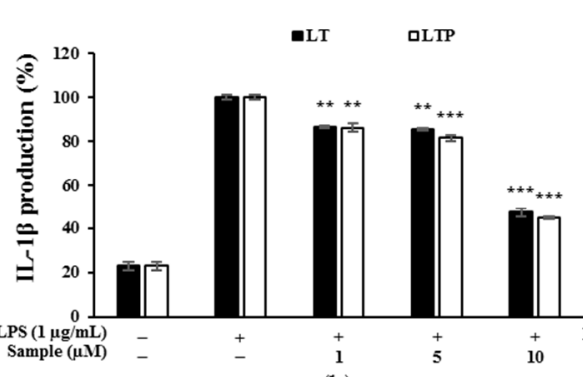

(b)

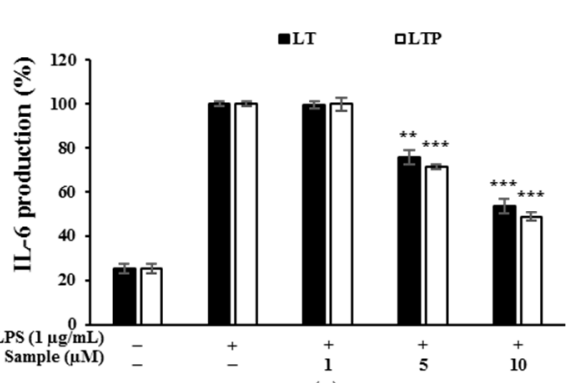

(c)

Figure 5. Comparison of the inhibitory effects of LT and LTP on LPS-induced (a) tumor necrosis factor- $\alpha$ (TNF- $\alpha$ ), (b) interleukin-1 $\beta$ (IL-1 $\beta$ ), and (c) interleukin-6 (IL-6) production in RAW 264.7 macrophages. Data are expressed as mean \pm SD from three independent experiments ${ }^{*} p<0.05,{ }^{* *} p<0.01$, and ${ }^{* *} p<0.001$, compared to the LPS-treated group).

\subsection{Effects of LT and LTP on the Activation of NF- $\kappa B$ and MAPK}

NF-kB is known to regulate the expression of proinflammatory cytokines. Moreover, MAPK is involved in inflammation and plays an important role in the activation of NF-kB. As a result of understanding the MAPK regulation by analyzing p38, ERK, and JNK, as shown in Figure 6, LT slightly inhibited p38, whereas LTP decreased MAPK in a concentration-dependent manner. In particular, it was shown that p38 and ERK were significantly reduced by LTP. IKB- $\alpha$, which rapidly changes NF- $\mathrm{kB}$ activation, is phosphorylated and degrades IкB- $\alpha$ to phospho IкB- $\alpha$. Phospho IкB- $\alpha$ is known to decrease the inflammatory response with increased expression. LTP more potently inhibited NF- $\mathrm{KB}$ and increased the expression of IкB- $\alpha$ more effectively than LT in a concentration-dependent manner. These results show that the reduction in the inflammatory factors and mediators increased by LPS in RAW 264.7 cells is regulated by MAPK and NF- $\mathrm{kB}$ inhibition is regulated by LTP.

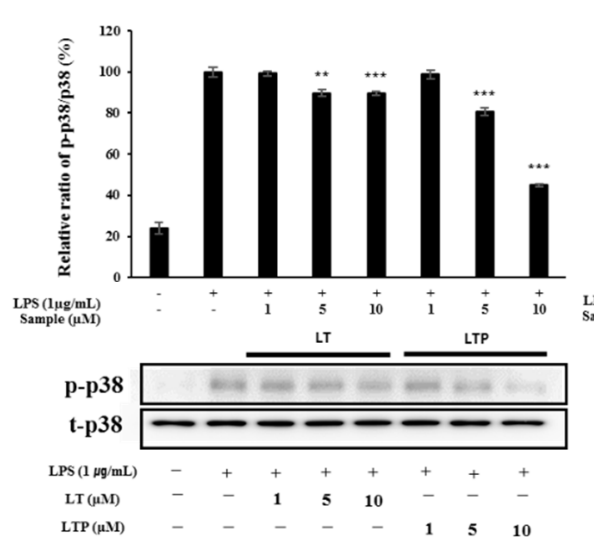

(a)

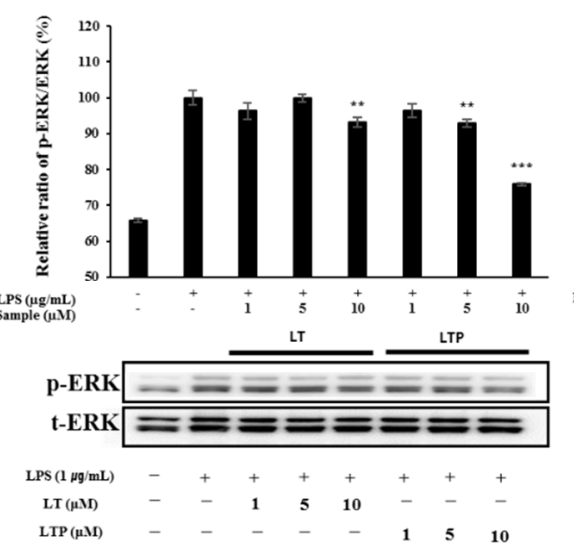

(b)

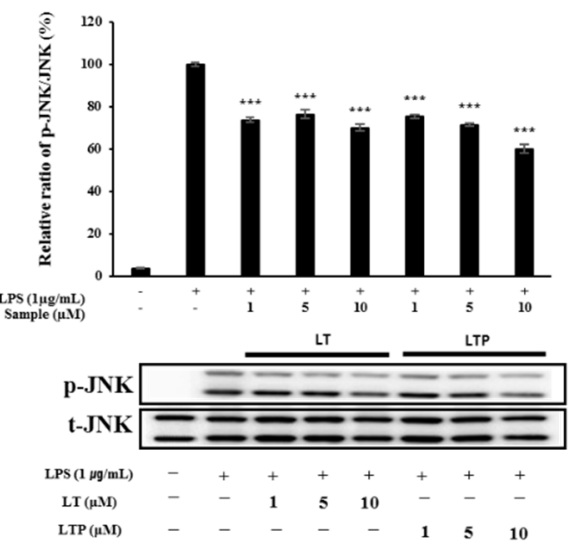

(c)

Figure 6. Cont. 


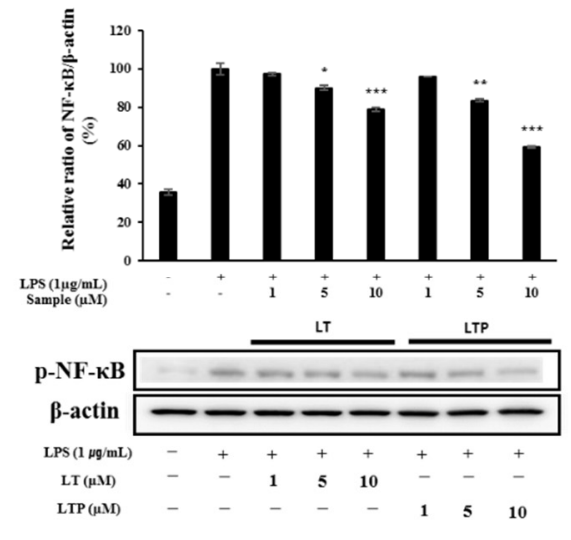

(d)

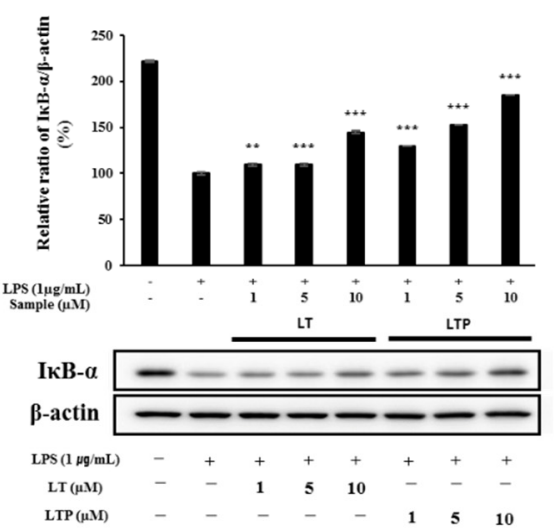

(e)

Figure 6. Effects of LT and LTP on the expression levels of mitogen-activated protein kinase (MAPK) and nuclear factorkappa B (NF-KB) in LPS-stimulated RAW 264.7 cells for (a) p38, (b) extracellular signal-regulated kinase (ERK), (c) c-jun $\mathrm{NH}_{2}$-terminal kinase (JNK), (d) nuclear factor-kappa B (NF- $\left.\mathrm{BB}\right)$, and (e) I $\mathrm{B}$ - $\alpha$. Data are expressed as mean $\pm \mathrm{SD}$ from three independent experiments $\left({ }^{*} p<0.05,{ }^{* *} p<0.01\right.$, and ${ }^{* *} p<0.001$, compared to the LPS-treated group).

\section{Discussion}

Here, we attempted to develop a new anti-inflammatory agent through biorenovation using LT as a substrate. We used MS and NMR to identify this compound as LTP. We then investigated the anti-inflammatory activity of LTP. In RAW 264.7 cells stimulated by LPS, both LT and LTP slightly decreased the levels of pro-inflammatory factors and kinases but, at the same time, showed different mechanisms of action. In conclusion, LTP inhibited the activation of MAPK-dependent inflammation more strongly than LT.

Inflammation refers to how tissue responds when it is damaged. It can be caused by an increase in inflammatory cytokines, free radical production, or LPS secretion. The overproduction of $\mathrm{NO}$ by iNOS and $\mathrm{PGE}_{2}$ by COX-2 is known as a common reaction to inflammation [31]. In the present study, we found that both LT and LTP decreased NO and $\mathrm{PGE}_{2}$ production in a dose-dependent manner. As a result of confirming iNOS and COX-2, which are known as upstream mechanisms of $\mathrm{NO}$ and $\mathrm{PGE}_{2}$, through Western blot, it was confirmed that they decreased in a concentration-dependent manner. We found that, at the experimental concentration, LTP inhibited the production of $\mathrm{NO}$ and $\mathrm{PGE}_{2}$ and inhibited the expression of iNOS and COX- 2 more than LT. TNF- $\alpha$, IL-6, and IL- $1 \beta$, known as proinflammatory cytokines, play an important role in inducing tissue damage and mediating several inflammatory diseases [32]. LT was found to decrease the secretion of TNF- $\alpha$, IL-6, and IL-1 $\beta$ in a previous study [33]. As shown in Figure 4, LTP also decreased the secretion of TNF- $\alpha$ and IL- 6 . As a result of confirming the production rates of TNF- $\alpha$, IL-6, and IL-1 $\beta$, LTP showed higher inhibition than LT in all the experiments. These results suggest that LTP exhibits stronger anti-inflammatory activity than LT. The transcriptional regulator NF- $\mathrm{kB}$ plays an important role in the inflammatory response because it has the ability to induce the transcription of gene sequences associated with inflammation, so it can specifically induce the regulation of pro-inflammatory molecules [34]. NF- $\mathrm{kB}$ forms the inhibitor I $\mathrm{kB}$ under normal physiological conditions. When I $\mathrm{kB}$ is phosphorylated, NF- $\mathrm{kB}$ translocates to the nucleus to activate the target gene [35]. In contrast to I $\kappa \mathrm{B}-\alpha$ degradation, which leads to a sharp change in NF- $\mathrm{kB}$ activation, IKB-b degradation is known to be associated with prolonged NF- $\mathrm{KB}$ activation $[36,37]$. Furthermore, the activation of NF- $\mathrm{\kappa B}$ not only affects iNOS and COX-2 but also affects several genes involved in inflammatory action [38]. LT is known to significantly inhibit $\mathrm{NO}$ and $\mathrm{PGE}_{2}$ production due to NF- $\mathrm{kB}$ and active protein- 1 inactivation $[29,33]$.

Here, we identified MAPK and NF- $\mathrm{kB}$ via Western blotting to compare the signaling pathways for the anti-inflammatory effects of LT and LTP. We found that LTP decreased NF- $\kappa B$ phosphorylation and increased I $\kappa B-\alpha$ expression more effectively than LT at $10 \mu \mathrm{M}$, 
suggesting that LTP inhibits IкB- $\alpha$ and inactivates NF- $\mathrm{kB}$, thereby suppressing the expressions of iNOS and COX-2. Among the MAPKs, p38 and JNK are stress-activated protein kinases that play essential roles in apoptosis and inflammation [39]. This signaling pathway activates AP-1 and NF- $\mathrm{KB}$ [40]. We examined MAPK to confirm further the mechanism of NF- $K B$ inactivation for LT and LTP, revealing that LTP exhibited higher inhibition rates than LT for p38, JNK, and ERK. In particular, LTP effectively inhibited p38, unlike LT, which had a minimal inhibitory effect. Overall, LTP downregulated the p38, JNK, and ERK signaling pathways between MAPKs more than LT and inhibited NF- $\mathrm{KB}$.

We confirmed that the reduction in the production of iNOS, COX-2, and pro-inflammatory cytokines induced by LPS was caused by the regulation of the MAPK and NF- $\mathrm{kB}$ signaling pathways through the experimental results. Both LT and LTP showed anti-inflammatory activity because they regulate the same signaling pathways, but LTP showed more effective inhibitory activity than LT on p38, ERK, NF- $\mathrm{BB}$, and IкB. This result suggests that the higher anti-inflammatory effect of LTP compared to that of LT was because of its more superior inhibitory activity on the MAPK and NF- $\mathrm{kB}$ pathways compared to LT. LPS-induced NF- $\mathrm{kB}$ and AP-1 activation have been reported to be regulated by a series of events that lead to the activation of MAPK and Akt [41-43]. Thus, we suggest that further studies comparing Akt phosphorylation inhibitory activity are needed to understand the signaling pathways involved in the anti-inflammatory activities of LT and LTP. Our study confirmed that a material synthesized through biorenovation exhibited higher anti-inflammatory activity than that of its substrate. Our findings also suggest that LTP, a compound synthesized through biorenovation, can be used to develop effective anti-inflammatory drugs.

\section{Materials and Methods}

\subsection{Reagents and Strains Used in Biorenovation}

LT was obtained from Sigma-Aldrich (St. Louis, MO, USA). Nutrient medium components were obtained from Difco (Baltimore, MD, USA). Bacillus sp. JD3-7 strain (KCTC92346P) was obtained from the Korean Collection for Type Cultures (Seoul, Korea).

\subsection{Biorenovation of $L T$}

For the seed culture, Bacillus sp. JD3-7 colonies were placed in a culture tube containing $4 \mathrm{~mL}$ of nutrient broth (peptone [ThermoFisher, Waltham, MA, USA] and beef extract [ThermoFisher]) and cultured for $16 \mathrm{~h}$. Then, $100 \mathrm{~mL}$ of nutrient medium was placed in a $500 \mathrm{~mL}$ flask, adding $0.2 \%$ of the total volume to Bacillus sp. JD3-7 cells were added. The flask was then incubated for $16 \mathrm{~h}$, shaking at $150 \mathrm{rpm}$ in an incubator at $30^{\circ} \mathrm{C}$. The culture medium was then centrifuged at $3577 \times g$ for $15 \mathrm{~min}$; only the bacterial pellet was recovered. The obtained pellet was washed twice with PG buffer $(50 \mathrm{mM}$ phosphate buffer, $2 \%$ glycerol, $\mathrm{pH}$ 7.2). The washed bacterial pellet, PG buffer, and $50 \mathrm{mg}$ of LT were then placed in a $500 \mathrm{~mL}$ flask and incubated for $72 \mathrm{~h}$, shaking at $150 \mathrm{rpm}$ in an incubator at $30^{\circ} \mathrm{C}$. After incubation, centrifugation was performed at $4416 \times g$ for $10 \mathrm{~min}$ using a centrifuge, and the divided supernatant was freeze-dried and powdered. For more accurate separation and identification, ethyl acetate (EA, DAEJUNG, Busan, Korea) fractionation was performed. The sample was dissolved in purified water, and twice the amount of EA was added to separate the layers. The water layer and the EA layer were recovered separately and repeated 3 times. The separated layers were each concentrated and sampled.

\subsection{HPLC Analysis of the LT Biorenovation Product}

HPLC analysis was performed using a Shimadzu SpectroMonitor 3200 equipped with a Shim-pack GIS $0.5 \mathrm{~mm}$ ODS C18 column $(250 \times 4.6 \mathrm{~mm}$ id), with the mobile phase consisting of solvent $\mathrm{A}(0.1 \% v / v$ trifluoroacetic acid in water) and B (acetonitrile). A gradient method was used in which the flow rate of solvent $\mathrm{B}(1 \mathrm{~mL} / \mathrm{min})$ was increased from $10 / 90$ to $50 / 50$ over $30 \mathrm{~min}$. The column temperature was maintained at $40{ }^{\circ} \mathrm{C}$. The wavelength was measured at $254 \mathrm{~nm}$. 
4.4. Liquid Chromatography-Mass Spectrometry (LC-MS) and Nuclear Magnetic Resonance (NMR) of the LT Biorenovation Product

LC/MS analysis of LTP was confirmed in positive ion mode using Agilent 1260 Infinity II (Agilent, Santa Clara, CA, USA). Luna ${ }^{\circledR}$ C18(2) $(2 \mathrm{~mm} \times 100 \mathrm{~mm}, 3 \mu \mathrm{m}$ particle size) columns were used for the analysis. $5 \mu \mathrm{L}$ of LT and LTP were injected into the C18 column and eluted at a flow rate of $300 \mu \mathrm{L} / \mathrm{min}$. The mobile phase was composed of solvent $\mathrm{A}$ $(0.1 \% v / v$ formic acid in water) and B (acetonitrile) and increased from 10/90 to 5/95 over $12 \mathrm{~min}$. The column temperature was maintained at $40^{\circ} \mathrm{C}$. The wavelength was measured at $254 \mathrm{~nm}$. The spectrum used for NMR analysis was prepared from a VNMRS 500 NMR spectrometer (Agilent Technology, Santa Clara, CA, USA), and residual solvent peaks $\left(\right.$ DMSO- $\left.\mathrm{d}_{6}=\delta_{\mathrm{H}} 2.50\right)$ of deuterated NMR solvent (Sigma-Aldrich, St. Louis, MO, USA) were used as a reference peak.

\subsection{Cell Culture, Treatment, and Cell Viability Assay}

The RAW 264.7 cell line was purchased from the Korean Cell Line Bank (Seoul, Korea) and cultured in Dulbecco's modified Eagle's medium (Welgene, Gyeongsan, Korea); 10\% fetal bovine serum (Welgene, Gyeongsan, Korea) and $1 \%$ penicillin were added. Cells in 24well plates $\left(7 \times 10^{4}\right.$ cells per well) were incubated for $24 \mathrm{~h}$ with the indicated concentrations of LT and LTP $(1,5$, and $10 \mu \mathrm{M})$ with or without LPS $(1 \mu \mathrm{g} / \mathrm{mL})$ in a humid atmosphere containing $5 \% \mathrm{CO}_{2}$ at $37^{\circ} \mathrm{C}$. Cell viability was measured using a 3(4,5-dimethyl-2-thiazolyl)2,5-diphenyl tetrazolium bromide (MTT) assay [44]. Cultured cells were incubated with the MTT reagent $(1 \mathrm{mg} / \mathrm{mL})$ at $37^{\circ} \mathrm{C}$ for $4 \mathrm{~h}$. After removing the media, the formazan crystals were dissolved in dimethyl sulfoxide and placed onto a 96-well plate at $100 \mu \mathrm{L}$ cells per well. Absorbance was measured via a microplate reader with the wavelength value set to $570 \mathrm{~nm}$ (Spectrophotometer, ThermoFisher, Waltham, MA, USA).

\subsection{Nitrite and Prostaglandin $E_{2}\left(P G E_{2}\right)$ Level Determination}

RAW 264.7 cells were seeded onto 24 -well plates $\left(7.0 \times 10^{4}\right.$ cells per well $)$ and incubated for $24 \mathrm{~h}$. Then, with or without $1 \mu \mathrm{g} / \mathrm{mL}$ of LPS, various concentrations of either LT or $\operatorname{LTP}(1,5,10 \mu \mathrm{M})$ were added, and plates were incubated for $24 \mathrm{~h}$ for NO production. Griess reaction was used to measure the amount of NO accumulated in the medium. The $\mathrm{PGE}_{2}$ concentration in the cell culture supernatant was measured using an enzyme-linked immunosorbent assay (ELISA) kit (R\&D Systems Inc., Minneapolis, MN, USA).

\subsection{Measurement of pro-Inflammatory Cytokine Production (TNF- $\alpha, I L-1 \beta$, and IL-6)}

RAW 264.7 cells were seeded onto 24 -well plates $\left(7.0 \times 10^{4}\right.$ cells per well) and incubated for $24 \mathrm{~h}$. Then, with or without $1 \mu \mathrm{g} / \mathrm{mL}$ of LPS, various concentrations of either LT or $\operatorname{LTP}(1,5,10 \mu \mathrm{M})$ were added, and plates were incubated for $24 \mathrm{~h}$. Supernatants were used for pro-inflammatory cytokine assays using a mouse ELISA kit (R\&D Systems Inc., Minneapolis, MN, USA).

\subsection{Western Blot Analyses}

Whole-cell proteins from each sample were extracted using radioimmunoprecipitation assay buffer (BioRad, Hercules, CA, USA) and assayed with a Bradford assay kit (Pierce BCA Protein Assay Kit, Thermo, Waltham, MA, USA). After analysis, $20 \mu \mathrm{g}$ of protein was resolved in each sample by electrophoresis using a $10 \%$ sodium dodecyl sulfatepolyacrylamide gel. The digested proteins were transferred to polyvinylidene difluoride (PVDF) membranes (BioRad, Hercules, CA, USA) at $130 \mathrm{~V}$ for $2 \mathrm{~h}$. Following the transfer, the membranes were incubated in 5\% skim milk (BD, Franklin Lakes, NJ, USA) to block non-specific binding during subsequent immunostaining. Then, the membranes were incubated overnight at $4{ }^{\circ} \mathrm{C}$ with antibodies against iNOS, COX-2, p-JNK, p-NF- $\mathrm{B}$, pI $\mathrm{B}-\alpha, \mathrm{p}$-ERK, and p-p38. Membranes were washed 3 times with 10 min intervals using 10x Tris-buffered saline with Tween (TBST) and then incubated with the corresponding horseradish peroxidase (HRP)-conjugated secondary antibody for $1 \mathrm{~h}$ at room temperature. 
The membranes were then washed three times with $10 \times$ TBST at $10 \mathrm{~min}$ intervals, exposed to an enhanced chemiluminescence kit (BioRad, Hercules, CA, USA), and visualized on an image reader (LAS-4000, Fujifilm, Japan). After detection, the cells were incubated with antibodies against JNK, NF- $\mathrm{B}, \mathrm{I}$ BB- $\alpha$, ERK, p38, and $\beta$-actin. Immunostaining was repeated as described above. Band densities were determined after measurement using the ImageJ analysis program.

\subsection{Statistical Analysis}

All results were expressed as mean \pm standard deviation (SD) of the results of at least three independent experiments. The data obtained through the experiment were expressed by evaluating the statistical significance of the difference using Student's $t$-test.

Supplementary Materials: The following are available online, Table S1: ${ }^{1} \mathrm{H}\left(\mathrm{DMSO}_{-} \mathrm{D}_{6}, 500 \mathrm{MHz}\right.$ NMR) and ${ }^{13} \mathrm{C}$ (DMSO-D $6,125 \mathrm{MHz}$ NMR) NMR chemical shifts of luteolin $3^{\prime}$-O-phosphate (LTP), Figure S1: ${ }^{1} \mathrm{H}$ NMR spectra of luteolin $3^{\prime}-O$-phosphate (LTP), Figure S2: HSQC correlation of luteolin $3^{\prime}$-O-phosphate (LTP), Figure S3: HMBC correlation of luteolin $3^{\prime}$-O-phosphate (LTP), Figure S4: COSY correlation of luteolin $3^{\prime}$-O-phosphate (LTP).

Author Contributions: Conceptualization, S.-Y.K. and W.-J.C.; formal analysis, J.-H.K., T.-J.P. and J.-S.P.; data curation, J.-H.K., T.-J.P., J.-S.P. and M.-S.K.; writing-original draft preparation, J.-H.K.; writing-review and editing, S.-Y.K. and W.-J.C.; supervision, S.-Y.K.; project administration, S.-Y.K.; All authors have read and agreed to the published version of the manuscript.

Funding: This research was supported by a grant from the National Institute of Biological Resources (NIBR), funded by the Ministry of Environment (MOE) of the Republic of Korea (NIBR202102109).

Institutional Review Board Statement: Not applicable.

Informed Consent Statement: Not applicable.

Data Availability Statement: Not applicable.

Acknowledgments: This research was financially supported by the Ministry of Health and Welfare (MOHW) and the "Dermatology Applied Materials-Leading Technology Development (R\&D, HP20C0231)" project of the Korea Health Industry Development Institute (KHIDI).

Conflicts of Interest: The authors declare no conflict of interest.

Sample Availability: Samples of the compounds are not available from the authors.

\section{References}

1. Choi, H.J.; Eun, J.-S.; Park, Y.-R.; Kim, D.K.; Li, R.; Moon, W.S.; Park, J.M.; Kim, H.S.; Cho, N.-P.; Cho, S.-D.; et al. Ikarisoside A inhibits inducible nitric oxide synthase in lipopolysaccharide-stimulated RAW 264.7 cells via p38 kinase and nuclear factor-kappaB signaling pathways. Eur. J. Pharmacol. 2008, 601, 171-178. [CrossRef]

2. Becker, S.; Mundandhara, S.; Devlin, R.B.; Madden, M.C. Regulation of cytokine production in human alveolar macrophages and airway epithelial cells in response to ambient air pollution particles: Further mechanistic studies. Toxicol. Appl. Pharmacol. 2005, 207, 269-275. [CrossRef]

3. Moretta, A.; Marcenaro, E.; Sivori, S.; Della Chiesa, M.; Vitale, M.; Moretta, L. Early liaisons between cells of the innate immune system in inflamed peripheral tissues. Trends Immunol. 2005, 26, 668-675. [CrossRef]

4. Lopes, A.J.O.; Vasconcelos, C.C.; Pereira, F.A.N.; Silva, R.H.M.; Queiroz, P.F.D.S.; Fernandes, C.V.; Garcia, J.B.S.; Ramos, R.; Da Rocha, C.Q.; Lima, S.T.D.J.R.M.; et al. Anti-Inflammatory and Antinociceptive Activity of Pollen Extract Collected by Stingless Bee Melipona fasciculata. Int. J. Mol. Sci. 2019, 20, 4512. [CrossRef]

5. Lawrence, T.; Willoughby, D.A.; Gilroy, D.W. Anti-inflammatory lipid mediators and insights into the resolution of inflammation. Nat. Rev. Immunol. 2002, 2, 787-795. [CrossRef]

6. Allavena, P.; Garlanda, C.; Borrello, M.G.; Sica, A.; Mantovani, A. Pathways connecting inflammation and cancer. Curr. Opin. Genet. Dev. 2008, 18, 3-10. [CrossRef]

7. Luan, H.; Zhang, Q.; Wang, L.; Wang, C.; Zhang, M.; Xu, X.; Zhou, H.; Li, X.; Xu, Q.; He, F.; et al. OM85-BV induced the productions of IL-1 $\beta$, IL-6, and TNF- $\alpha$ via TLR $4_{-}$and TLR 2 -mediated ERK1/2/NF-kB Pathway in RAW264.7 Cells. J. Interferon Cytokine Res. 2014, 34, 526-536. [CrossRef]

8. Sacco, R.E.; Waters, W.R.; Rudolph, K.M.; Drew, M.L. Comparative nitric oxide production by LPS-stimulated monocyte-derived macrophages from Ovis canadensis and Ovis aries. Comp. Immunol. Microbiol. Infect. Dis. 2006, 29, 1-11. [CrossRef] [PubMed] 
9. Kaplanski, G.; Marin, V.; Montero-Julian, F.; Mantovani, A.; Farnarier, C. IL-6: A regulator of the transition from neutrophil to monocyte recruitment during inflammation. Trends Immunol. 2003, 24, 25-29. [CrossRef]

10. Park, J.Y.; Pillinger, M.H.; Abramson, S.B. Prostaglandin $\mathrm{E}_{2}$ synthesis and secretion: The role of PGE 2 synthases. Clin. Immunol. 2006, 199, 229-240. [CrossRef] [PubMed]

11. Warren, J.S. Interleukins and tumor necrosis factor in inflammation. Crit. Rev. Clin. Lab. Sci. 1990, 28, 37-59. [CrossRef]

12. Karin, M.; Ben-Neriah, Y. Phosphorylation meets ubiquitination: The control of NF-[kappa]B activity. Ann. Rev. Immunol. 2000, 18, 621-663. [CrossRef] [PubMed]

13. Grilli, M.; Chiu, J.J.-S.; Lenardo, M.J. NF-kappa B and Rel: Participants in a Multiform Transcriptional Regulatory System. Int. Rev. Cytol. 1993, 143, 1-62. [CrossRef] [PubMed]

14. Pateras, I.; Giaginis, C.; Tsigris, C.; Patsouris, E.; Theocharis, S. NF- $\mathrm{BB}$ signaling at the crossroads of inflammation and atherogenesis: Searching for new therapeutic links. Expert Opin. Ther. Targets 2014, 18, 1089-1101. [CrossRef]

15. Tak, P.P.; Firestein, G.S. NF-kappaB: A key role in inflammatory diseases. J. Clin. Investig. 2001, 107, 7-11. [CrossRef]

16. Pautz, A.; Art, J.; Hahn, S.; Nowag, S.; Voss, C.; Kleinert, H. Regulation of the expression of inducible nitric oxide synthase. Nitric Oxide 2010, 23, 75-93. [CrossRef] [PubMed]

17. Zhishen, J.; Mengcheng, T.; Jianming, W. The determination of flavonoid contents in mulberry and their scavenging effects on superoxide radicals. Food Chem. 1999, 64, 555-559. [CrossRef]

18. Kim, B.H.; Jang, J.O.; Lee, J.-H.; Park, Y.E.; Kim, J.-G.; Yoon, Y.-C.; Jeong, S.J.; Kwon, G.-S.; Lee, J.-B. Increased Anti-oxidative Activity and Whitening Effects of a Saposhnikovia Extract Following Bioconversion Fermentation using Lactobacillus plantarum BHN-LAB 33. J. Life Sci. 2019, 29, 1208-1217. [CrossRef]

19. Choi, H.R.; Park, J.-S.; Kim, K.M.; Kim, M.S.; Ko, K.W.; Hyun, C.-G.; Ahn, J.W.; Seo, J.-H.; Kim, S.Y. Enhancing the antimicrobial effect of genistein by biotransformation in microbial system. Ind. Eng. Chem. 2018, 63, 255-261. [CrossRef]

20. Kim, J.H.; Park, T.J.; Sim, J.H.; Kim, S.Y. The Effects of Gleditsia japonica Extract Following Biorenovation on Melanogenesis-related genes in B16F10 Melanoma Cells. KSBB J. 2020, 35, 303-309. [CrossRef]

21. Kim, M.S.; Park, T.J.; Lim, J.S.; Kim, S.Y. Effect of Agaricus biorenovate Extract on Collagen Synthesis and Matrix Metalloproteinase-1 Production in Human Dermal Fibroblast. KSBB J. 2019, 34, 49-53. [CrossRef]

22. Middleton, E.; Kandaswami, C.; Theoharides, T.C. The effects of plant flavonoids on mammalian cells: Implications for inflammation, heart disease, and cancer. Pharmacol. Rev. 2000, 52, 673-751.

23. García-Lafuente, A.; Guillamón, E.; Villares, A.; Rostagno, M.A.; Martínez, J.A. Flavonoids as anti-inflammatory agents: Implications in cancer and cardiovascular disease. Inflamm. Res. 2009, 58, 537-552. [CrossRef]

24. Wang, S.; Cao, M.; Xu, S.; Shi, J.; Mao, X.; Yao, X.; Liu, C. Luteolin alters macrophage polarization to inhibit inflammation. Inflammation 2020, 43, 95-108. [CrossRef] [PubMed]

25. Farzaei, M.H.; Abbasabadi, Z.; Ardekani, M.R.S.; Rahimi, R.; Farzaei, F. Parsley: A review of ethnopharmacology, phytochemistry and biological activities. J. Tradit. Chin. Med. 2013, 33, 815-826. [CrossRef]

26. Katiyar, C.; Gupta, A.; Kanjilal, S.; Katiyar, S. Drug discovery from plant sources: An integrated approach. Ayu 2012, 33, 10-19. [CrossRef] [PubMed]

27. Hong, H.H.; Park, T.J.; Kang, M.S.; Kim, S.Y. Anti-inflammatory Activity of Beta vulgaris Extract Using Biorenovation in LPS-stimulated RAW 264.7 Cells. Korean Soc. Biotechnol. Bioeng. J. 2021, 36, 123-129. [CrossRef]

28. Park, T.J.; Sim, J.H.; Hong, H.H.; Han, D.H.; Kim, S.Y. Anti-inflammatory Effect of Colocasia esculenta Biorenovate Extract in LPS-stimulated RAW 264.7 Cells. Korean Soc. Biotechnol. Bioeng. J. 2020, 35, 162-168. [CrossRef]

29. Park, C.M.; Song, Y.S. Luteolin and luteolin-7-O-glucoside inhibit lipopolysaccharide-induced inflammatory responses through modulation of NF-кB/AP-1/PI3K-Akt signaling cascades in RAW 264.7 cells. Nutr. Res. Pract. 2013, 7, 423-429. [CrossRef]

30. Li, J.; Wang, Y.; Lei, J.C.; Hao, Y.; Yang, Y.; Yang, C.X.; Yu, J.Q. Sensitisation of ovarian cancer cells to cisplatin by flavonoids from Scutellaria barbata. Nat. Prod. Res. 2014, 10, 683-689. [CrossRef] [PubMed]

31. Surh, Y.J. Cancer chemoprevention with dietary phytochemicals. Nat. Rev. Cancer 2003, 3, 768-780. [CrossRef] [PubMed]

32. Lee, A.K.; Sung, S.H.; Kim, Y.C.; Kim, S.G. Inhibition of lipopolysaccharide-inducible nitric oxide synthase, TNF- $\alpha$ and COX-2 expression by sauchinone effects on I-kB $\alpha$ phosphorylation, C/EBP and AP-1 activation. Br. J. Pharmacol. 2003, 139, 11-20. [CrossRef] [PubMed]

33. Chen, C.Y.; Peng, W.H.; Tsai, K.D.; Hsu, S.L. Luteolin suppresses inflammation-associated gene expression by blocking NF-kappaB and AP-1 activation pathway in mouse alveolar macrophages. Life Sci. 2007, 81, 1602-1614. [CrossRef] [PubMed]

34. Kim, S.H.; Shin, T.Y. Anti-inflammatory effect of leaves of Eriobotrya japonica correlating with attenuation of p38 MAPK, ERK, and NF-kappaB activation in mast cells. Toxicol. In Vitro 2007, 23, 1215-1219. [CrossRef]

35. Israf, D.A.; Khaizurin, T.A.; Lajis, N.H.; Khozirah, S. Cardamonin inhibits COX and iNOS expression via inhibition of p65NFkappaB nuclear translocation and Ikappa-B phosphorylation in RAW264.7 macrophage cells. Mol. Immunol. 2006, 44, 673-679. [CrossRef] [PubMed]

36. Park, H.J.; Kim, I.T.; Won, J.H.; Jeong, S.H.; Park, E.Y.; Nam, J.H.; Choi, J.W.; Lee, K.T. Anti-inflammatory activities of ent-16alphaH, 17-hydroxy-kauran-19-oic acid isolated from the roots of Siegesbeckia pubescens are due to the inhibition of iNOS and COX-2 expression in RAW 264.7 macrophages via NF-kappaB inactivation. Eur. J. Pharmacol. 2007, 558, 185-193. [CrossRef] [PubMed] 
37. Park, J.S.; Lee, E.J.; Lee, J.C.; Kim, W.K.; Kim, H.S. Anti-inflammatory effects of short chain fatty acids in IFN-gamma-stimulated RAW 264.7 murine macrophage cells: Involvement of NF-kappaB and ERK signaling pathways. Int. Immunopharmacol. 2007, 7, 70-77. [CrossRef] [PubMed]

38. Tsai, S.H.; Lin-Shiau, S.Y.; Lin, J.K. Suppression of nitric oxide synthase and the down-regulation of the activation of NF-kappaB in macrophages by resveratrol. Br. J. Pharmacol. 1999, 126, 673-680. [CrossRef] [PubMed]

39. Xia, Z.; Dickens, M.; Raingeaud, J.; Davis, R.J.; Greenberg, M.E. Opposing effects of ERK and JNK-p38 MAP kinases on apoptosis. Science 1995, 24, 1326-1331. [CrossRef] [PubMed]

40. Guha, M.; Mackman, N. LPS induction of gene expression in human monocytes. Cell Signal. 2001, 13, 85-94. [CrossRef]

41. Park, C.M.; Park, J.Y.; Noh, K.H.; Shin, J.H.; Song, Y.S. Taraxacum officinale Weber extracts inhibit LPS-induced oxidative stress and nitric oxide production via the NF-kB modulation in RAW 264.7 cells. J. Ethnopharmacol. 2011, 133, 834-842. [CrossRef] [PubMed]

42. Park, C.M.; Jin, K.S.; Lee, Y.W.; Song, Y.S. Luteolin and chicoric acid synergistically inhibited inflammatory responses via inactivation of PI3K-Akt pathway and impairment of NF-кB translocation in LPS stimulated RAW 264.7 cells. Eur. J. Pharmacol. 2011, 660, 454-459. [CrossRef] [PubMed]

43. Lee, J.P.; Li, Y.C.; Chen, H.Y.; Lin, R.H.; Huang, S.S.; Chen, H.L.; Kuan, P.C.; Liao, M.F.; Chen, C.J.; Kuan, Y.H. Protective effects of luteolin against lipopolysaccharide-induced acute lung injury involves inhibition of MEK/ERK and PI3K/Akt pathways in neutrophils. Acta Pharmacol. Sin. 2010, 31, 831-838. [CrossRef]

44. Mosmann, T. Rapid colorimetric assay for cellular growth and survival: Application to proliferation and cytotoxicity assays. J. Immunol. Methods 1983, 65, 55-63. [CrossRef] 